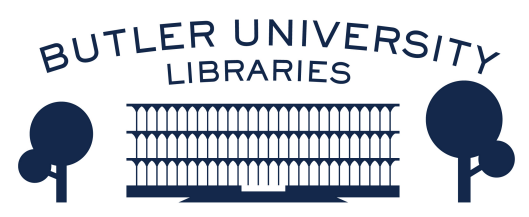

Journal of Hindu-Christian Studies

Volume 9

Article 17

January 1996

\title{
Book Review: "Majesty and Meekness: A Comparative Study of Contrast and Harmony in the Concept of God"
}

Michael Stoeber

Follow this and additional works at: https://digitalcommons.butler.edu/jhcs

Part of the Religion Commons

\section{Recommended Citation}

Stoeber, Michael (1996) "Book Review: "Majesty and Meekness: A Comparative Study of Contrast and Harmony in the Concept of God"," Journal of Hindu-Christian Studies: Vol. 9, Article 17.

Available at: https://doi.org/10.7825/2164-6279.1139

The Journal of Hindu-Christian Studies is a publication of the Society for Hindu-Christian Studies. The digital version is made available by Digital Commons @ Butler University. For questions about the Journal or the Society, please contact cbauman@butler.edu. For more information about Digital Commons @ Butler University, please contact digitalscholarship@butler.edu. 
Abhishiktananda. One could call it an experiment and evaluate its success and drawbacks. But Abhishiktananda remains as a dialogue between two traditions in his life. One cannot ignore an approach of this type in the Hindu-Christian encounter. Such "experiments" cannot be measured in terms of success or failure - and that could be said of the Christian presence in India in general or anywhere for that matter. The letters of Abhishiktananda reveal the struggles he underwent, his continuous search, his moments of enthusiasm and disappointment, and above all the seeking of the guidance of the Spirit. This book portrays the man as he was in his spiritual journey - his concern, his frustration, his perseverance in keeping the mission in sight; admitting his inadequacy, and so on.

It is not a theology that is to be judged in such an attempt. The process is more important than the product. Whether he achieved anything tangible is the wrong question to ask. The vibrant presence of such a pursuit is a value in itself. Those who look for such results are not the ones who understand the ashram ideal, the value of silence or of being a witness. The spirit behind such a pursuit is what inspires others. Abhishiktananda's diaries have such a lyrical charm that they attract the readers with spontaneity and freshness. His intellectual stamina to keep writing - to reflect, to articulate, to reformulate, summarize, etc., given the conditions in which he lived - is something admirable.

In the history of the Indian Church he occupies an important place - as one of the "Fathers of the Indian Church" - acting as a spiritual and theological ferment. In fact attempts are made to evaluate his Christology and his understanding of Christ from his writings. Abhishiktananda responds to such questions thus:

There is a message from India which must be passed on... But this message is not conveyed in words. Souls have to be opened up from within... There are people for whom the advaitin experience is an existential matter, and others for whom it is speculative and worse still, certain people identify it with the ideas of those who follow Guenon and other esotericists. So they do not understand the real problem. They argue and then pass sentence in the name of the faith, without really noticing that this experience is precisely summoning the faith to a great purification. (p.161)

Abhishiktananda is usually portrayed as a man of advaitic enlightenment. With all his search for the Absolute, he remained quite "earthy" - concerned about the poor who died of starvation and sickness. And this volume reveals the man Abhishiktananda. Those who have not seen him or read any of his writings will find this book quite valuable and those who are aware of his writings will discover in this book another dimension of Abhishiktananda.

Anand Amaladass, S.J.

Madras

\section{Majesty and Meekness: A Comparative Study of Contrast and Harmony in the Concept of God. John B. Carman. Grand Rapids, Michigan: William B. Berdmans Publishing Company, 1994, 453 pp., incl. glossary and index.}

JOHN CARMAN HAS brought together in this book a wide variety of ideas from different religious traditions about the nature of the divine Reality. Acknowledging and 
reflecting his own faith stance, he writes as a Christian who is deeply involved in the phenomenological, historical venture of understanding through empathetic imagination the religious perspectives of what he calls "God" in Christian, Hindu, Buddhist, Islamic, and Jewish thought.

One might wonder initially about the feasibility and even the value of such a vast comparative project, given the range of beliefs about the Divine in even particular movements and moments of a single tradition, as well as the intricacies of evaluative analysis that are required in good comparative studies of specific features of just two traditions. However, Professor Carman's comparison is specifically guided by certain tensions or polarities or paradoxes that are found in the ideas of particular representatives of these different traditions, and he deliberately refrains in this study from evaluative comment.

The framework of polarities provides an illuminating handle or structure by which to grasp various references to the Divine between different traditions. One might wonder about the criteria guiding the choice of some of the subjects and secondary commentators, but the book does give a highly informative and rather balanced account of central features of the nature of the Divine in various traditions, stressing differences as much or more than the remarkable convergences. It is a fine scholarly example of careful comparative phenomenology. Besides that, it is wonderful to read. Professor Carman's prose, even when it treats very obscure material, is gentle, fluid, clear, eloquent, personal, and accessible. The book will appeal to a wide audience, both to specialized scholars and non-specialists, be they Christian or not.

Professor Carman is interested primarily in polarities, that is, in the contrasting or opposing ideas about the Divine. $\mathrm{He}$ is concerned with how different religious thinkers envision and treat such polarities. The polarities he cites involve deep conceptual tensions which are treated by theologians and devotees in different ways: either they are thought to be somehow complementary, perhaps through a hierarchical ranking or mysterious reconciliation in the Divine; or to be contradictory, with perhaps even the rejection of one side of the polarity; or to be transcended in religious experience; or to be simply ignored.

The analysis is guided primarily by two general polarities. The first general polarity has to do with the Divine proper: supremacy / accessibility. But it is best clarified, I think, by the traditional dichotomy between the impersonal (or transpersonal) and personal nature of the Divine. The former is typically described in terms which depict it as One or Unity, and as inactive and amoral. This is contrasted starkly from the personal aspect, which is described in various ways as somehow differentiated, active, creative, and moral. Naturally, then, whithin this general polarity we might include some of Professor Carman's other dichotomies: transcendence / immanence; unity / diversity; independence (or self-sufficiency)

dependence; highness / humble condescension; purity / attributes; and nirvana / samsara. But within the personal pole itself, we also find in certain traditions other fascinating tensions: destroyer 1 preserver; masculine / feminine; and ascetic / erotic.

The second general polarity has more to do with the relation of the Divine to the phenomenal world and humanity. This is justice / grace, under which I would include the contrasting qualities of wrath ! forgiveness (or mercy), and divine power (or omniscience) / human freedom. But there are also other polarities which are more limited in their focus on the human condition and liberation, such as saving insight (or grace) / effort (or moral action).

The illustration of these polarities begins in Part Two with a survey of the devotional Śaivism or certain Tamil poet saints of the early middle ages, followed by an outline of 
the Srivaisnava theology of Nammalvar, Ramanuja, and Pillan. Basic ideas in Jodo Shinsu are then developed, and the paradoxical nature of shinjin ("true trusting mind") is related to the tension between grace and human effort in Srivaisnavism.

Part Three surveys Christian concepts, beginning with an interesting and unusual overview of ideas in the Presbyterian Church Hymnary, followed by the treatment of ideas from Martin Luther, and Jonathan and Sarah Edwards, focusing largely on the justice (or wrath) / mercy (or compassion) polarities. These polarities are also very relevant to Jewish thought, which leads Professor Carman to introduce related issues in theodicy, though Maimonides's treatment of the impersonal / personal polarities is also developed in that chapter.

Relevant features of these impersonal / personal dichotomies are further explored in Parts Three and Four, in terms of certain views of the Christian Trinity, Muslim monotheism, commentators on the mysticism of Sankkara and Eckhart, and in Part Five, in an outline of the thought of $E$. Cousins, $P$. Tillich, C. Hartshorne, and H. Berkhof. Comparative comments generally focus upon the subject matter of specific parts of the book, though there is some more general comparative overview running throughout the book. And Professor Carman does devote a specific chapter to a comparison of the Srivaishnava idea of avatar and the Christian idea of incarnation, and in another he compares Hindu Goddesses and the Virgin Mary.

The surveyed data in Majesty and Meekness is quite informative and provocative. Are traditional western semitic religions neglecting an important aspect of religious experience or fulfilment in their exclusion of the feminine in God and their rejection of the erotic pole? Are various polarities grounded in the divine nature or are they merely metaphorical, socio-cultural determinations? Are the attempted reconciliations of the wrath and love of God intelligible or plausible? Are ideas of wrath and predestination morally compatible with intelligent developments in theodicy? How, if at all, are certain polarities related to human development and spiritual transformation? Are specific religious or philosophical beliefs of some traditions more effective in the harmonization of certain poles?

These are just some of the many questions that came to mind as I read the book. Professor Carman seems well aware in his phenomenological development of many of these issues, but he tends to skirt such queries. He says his seeking in this works is one of "understanding", not evaluative explanation; "The phenomenological approach to theological concepts adopted in this study", he writes, "makes it impossible to engage here in an effort to explain polarities in the concept of God" (p.409). Still, his project seems somehow lacking or incomplete without further evaluative comment or summary or theory. In this regard, the concluding chapter, "Questions to Theologians", seems particularly indecisive and rather scattered in its attempt to summarize the issues.

The study would be enhanced, I think, through a shift in the concluding chapters, away from self-imposed phenomenological restraints, into the exploration of some of the more controversial evaluative questions that the data provoke. But Professor Carman feels that such an approach requires "a "separate study", one "that can clarify the basis for such an evaluation and place it in its appropriate setting within Christian systematic theology" (p.188). I look forward to such a companion volume, to compliment this fine phenomenological study of polar ideas concerning the Divine.

Michael Stoeber

The Catholic University of America Washington, D.C. 